\title{
An Appreciation of Fred McLafferty
}

\author{
Maurice M. Bursey
}

University of North Carolina at Chapel Hill, Chapel Hill, North Carolina, USA

$\mathrm{F}$ Tred McLafferty and I first met in the airport in Baltimore. It was the summer of 1964 and I had just accepted his offer of a postdoctoral appointment. He would be moving from Framingham to West Lafayette that fall, and was returning from a visit at Purdue to Dow. He made the point of rearranging his flight schedule to change planes in Baltimore so that he could talk with me about the problem on which I would work and give me background reading material on physical organic chemistry in the mass spectrometer. I was immediately struck by his energy, enthusiasm, and perspicacity. We had perhaps an hour to talk until his flight for Boston was called, and I found I had enough to keep me busy until we could meet again in September at Purdue.

The whole time we worked together I continued to be impressed with those qualities: energy, enthusiasm, and perspicacity. I watched him constantly to learn how to be an independent researcher, to deal with the public, to guide research students, to teach-I was even able to report to him once that an undergraduate had confided to me that McLafferty was the best professor he had had in class! The response was an enthusiastic "Maybe I should give up research and go into full-time teaching!" Fortunately for science, and for all of us, Fred was only joking.

Some years later, when I heard that Fred had been elected to the National Academy, I was pleased but not surprised. It had been clear to me from the outset that he was an extraordinary person, a careful planner, yet one who took full advantage of serendipity, a person who always had the big picture before him. The big picture was, of course, the marvelous problemsolving ability of the mass spectrometer, and if it took a sound background in analytical chemistry, organic chemistry, physical chemistry, or biological chemistry to focus that picture, he would either have that background or acquire it in record time. For the same reasons, I had not been surprised when he was named by the American Chemical Society to be editor of Accounts of Chemical Research. His interests truly covered the entire range of chemistry.

When he thought it would help me, Fred has from time to time given me frank advice. It has always been preceded by a sincere "Please don't take this personally, but...". These gentle exercises in thickening my skin began in my postdoctoral days. McLafferty alumni often trade stories about learning not to cringe when we heard those words.

All of us who have had the privilege to work for him and have gone on in this thrilling, ever-expanding area of science have stories like mine. They are based on those qualities that I have enumerated. Most of us have some of them to some degree, but Fred has each in a cornucopia.

Many more years to you, Fred! Please take that personally! 